\title{
AN EXPLORATORY CASE STUDY OF ONLINE EDUCATION AND INCORPORATION OF 21st CENTURY SKILLS IN SECONDARY CLASSROOMS
}

\author{
Subrata Biswas
}

Article DOI: https://doi.org/10.36713/epra6204

\begin{abstract}
Online learning through remote teaching is an upshot of the COVID-19 pandemic. But it has initiated immediate access to being online, collaborative and communicative, being critical thinkers and creative-settings that can facilitate $21^{\text {st }}$ Century skills. Today's students must be able to combine these skills with the effective use of technology to succeed in current and future jobs. The full promise of this learning is dependent, however, on institutions to train teacher's to incorporate $21^{\text {st }}$ century skills in its instructional design, delivery and implementation. Teachers must ensure that students who learn in online environments are gaining the skills necessary to compete as citizens and workers in the $21^{\text {st }}$ century.

Covid-19 has forced many countries to unchain its academia from its brick-and-mortar existence and embrace an online curriculum. Today, worldwide, students are taking classes, completing homework, and working on projects from their homes. Educators will have to shift their focus to incorporate teaching innovations like online tools, apps, animations and videos to capture the imagination of students while establishing engaging and meaningful communication.
\end{abstract}

This study focus on areas such as:

1. Preparedness Level of Teachers: Teachers need to be trained continuously so that they gain competence and confidence.

2. Satisfaction among Students and Teachers: This feeling can be leveraged upon to improve dexterity among students and teachers and enable them to achieve the desired learning outcomes.

3. Challenges - Online Education: Till the time the challenges are not tackled, the obstacles in the path of ensuring complete online education will not resolve.

4. Inequity in Online Education: The governments, at national and international levels needs to work on the front foot to ensure that accessibility and lack of device must not interfere with learning. The experiment of a 'Digital India' will remain a distant dream if a large population of students is gravely disadvantaged by this reality. Granted that the circumstances are peculiar, but it is the moral obligation of the State to ensure that fighting against COVID-19 does not exacerbate the disparities that already exist.

5. Strategies and Practices of 4Cs - a blended approach can be achieved in the post covid times, but since we do not know how long this period will take to come, the ground work should get started soon since the new normal will be a blended approach to learning.

6. Challenges $-21^{\text {st }}$ Century Skills- Teachers of the $20^{\text {th }}$ century need to upskill, unlearn and relearn the ways of the $21^{\text {st }}$ century by accepting that its time to retrain for the 4Cs to begin with as the holistic development of a learner will largely depend on the skills and competence of the teachers.

KEYWORDS: Online Education, 21st Century Skills, Critical thinking ,Creativity, Collaboration, Communication 


\subsection{INTRODUCTION}

\subsection{Background to the Problem}

Globally about 1.5 billion children are presently out of school due to COVID- 19 (UNESCO, 2020). The world is facing an unprecedented challenge, and in the education context, teachers, students and parents, around the world are in a confused state. Most schools these days have access to technology and internet and they are increasingly turning to online education. Students are using Zoom, Google Meet for classes and video calls, YouTube for education and leisure, online EdTech to learn. In the first decade of the 21st century, a broad range of attributes, dispositions and skills received considerable attention in educational research and policy. While most countries have developed a strong focus on 21 st century skills in their school education systems, this emphasis is still at the policy level rather than in practice and effective approaches for teaching and learning. Limited evidence on valid and reliable assessment exists. This calls for further investment in research on key skills for the 21st century, focusing particularly on teaching, learning and assessment (ACER, 2019). There is widespread consensus, however, that our education systems are failing to adequately prepare all students with the essential 21 st century knowledge and skills necessary to succeed in life, career and citizenship (OECD, 2010).

The Central Board of Secondary Education (CBSE) has recently launched '21st Century Skills: A Handbook' consisting of learning skills, life skills and literacy skills. "Simply teaching to test or learning for exams is not going to help a student face everyday life situations. 21st Century Skills are key to the empowerment of children and adolescents to deal with the issues and concerns related to their life.

They experience a number of feelings, many of which are related to their growth and development from childhood to adolescence and beyond..." (CBSE, 2020). The handbook has a list of activities that blend with the content. It emphasizes enhancing the learning skills of students through the learning skills of 4Cs - critical thinking, creativity \& innovation, collaboration, and communication.

Like other countries, India also aims to develop its education in all aspects of methods of teaching, learning materials and assessment strategies for all subjects in order to prepare its citizens for living effectively in the changing globe.

"...key overall thrust of curriculum and pedagogy reform across allstages will be to move the education system towards real understanding and learning how to learn - and away from the culture of rote learning presenttoday. The aim of education will not only be cognitive development, but also building character and creating holistic and well-rounded individuals equipped with the key 21 st century skills..." (National Education Policy, 2020)

Call it a quiet revolution the policymakers are bringing " 21 st century skills" to the classroom, prompting curriculum makers across the country to rewrite curriculum standards and even to contemplate big changes to existing systems.

"The National Education Policy lays particular emphasis on the development of the creative potential of each individual. It is based on the

principle that education must develop not only cognitive capacities - both the 'foundational capacities 'of literacy and numeracy and 'higher-order' cognitive capacities, such as critical thinking and problem solving - but also social, ethical, and emotional capacities and dispositions..." (National Education Policy, 2020)

\subsection{Research Objectives}

The following are research objectives form the basis of this exploratory case study:

(1) How do teachers, students in secondary schools and parents of the students perceive online education and the 4 Cs of 21 st century skills?

(2) Are teachers able to address the 4Cs of 21st century skills - critical thinking, creativity, collaboration, communication skills - while teaching with online technologies and how do they ensure that those are incorporated in the secondary class?

\subsection{Research Questions}

In order to describe the ways that teachers worked through remote teaching using technology and taking online classes and how they integrated 4Cs of the $21^{\text {st }}$ century skills into daily e-lessons, the following research questions were explored:

(1) How do teachers, students in secondary schools and parents of the students perceive online education and the 4 Cs of 21 st century skills?

(2) Are teachers able to address the 4Cs of 21st century skills - critical thinking, creativity, collaboration, communication skills - while teaching with online technologies and how do they ensure that those are incorporated in the secondary class?

\subsection{Delimitations and Limitations}

This study explored online education in only one secondary classroom in a single school. Since the study only described online education in one of the secondary schools in the state of West Bengal, India, 
generalization to other schools is limited, as differences in availability of technology, professional development in teaching with technology, age of the students and other demographic differences of the teachers and students vary between schools and can greatly impact how teachers use online education for the benefit of students.

\subsection{METHODOLOGY}

This study utilized a case study research design, a form of qualitative inquiry. The case study allowed for close examination of online education in a single secondary classroom. Examining the context (secondary classroom) was crucial in fully understanding and investigating the research questions. The case study is bounded by the delimitation of the lockdown due to the COVID pandemic and it was so overwhelming a situation that apart from telephonic interviews, conversations and discussions with multiple stakeholders, nothing in the other forms of data sources could come by. Therefore only information given by teachers, students and parents of a single secondary school in the urban city in the academic school year 2020-2021, has utilized.

\subsection{Research Population and Sampling Method}

Purposeful sampling is utilized frequently in qualitative studies to select participants who will provide the most beneficial information to the researcher. Within this case, although there were a number of teachers and their online classes at each secondary school, for the present case study, permission was granted by the Principal / Administrator of the school for an "unstructured telephonic interview" on the condition of no recording and complete and absolute anonymity and for filling up a structured open ended questionnaire. The research questions were allowed to be answered by the teachers and descriptions of the different ways that teachers perceived and used online education in secondary classes were allowed for discussion. The individual teachers utilizing online methodology in the classroom provided an in-depth description of teachers' perceptions on online education in their classroom. Qualitative data helped explain or build on the findings and determine whether any issues outside of the research questions influenced the delivery of online teaching.

2.2 Sources of Data Collection The researcher's strategy for collection of data included collection through the following tools: multiple interviews with students, teachers, parents; focus group conversations with students pooled together and questionnaires answered by experts -

teachers, students, parents and teacher educators and research scholars.

1. Questionnaire: Some questionnaire provided useful data and informed about how the participants valued the 21 st century skills and about their level of

understanding of the online education its benefits and challenges.

2. Interviews of students, teachers, parents and experts: Interviews were held with the teachers and students as well as the parents of the students and education experts.

3. Focus group discussions: The students collectively shared their learning experiences during their engagement in the online education.

4. Online data from websites and information from news on online education across the world: The researcher accessed information on the web pages

related to online education and found a similar thought process across the world which helped corroborate the researcher's theory that emerged out of the qualitative case study.

The interview schedules were semi structured to allow the required flexibility to incorporate new questions according to the demand of the context. The Interpretative validity of data was established by participant feedback method.

\subsection{Data analysis}

For data analysis the telephonic interviews and focus group discussions were transcribed verbatim for qualitative analysis. Interview transcripts were first openly coded to identify relevant codes. Qualitative thematic analyses were employed for the interviews and responses to the open-ended questions. The responses were coded independently with key words and brief descriptions and they were revised for consistent coding and categorizing. The questionnaires were similarly coded.

\subsection{Protection of Human Subjects}

This study provided teachers and students and parents of the students with as much ethical protection as possible. While the research did not present any apparent risks to participants, measures were taken in order to provide teachers and students with complete anonymity and accurate representation. Teachers participating in the research were assured of complete confidentiality and protection of participants' anonymity. 


\section{EPRA International Journal of Research and Development (IJRD)}

Participation in the proposed study was voluntary. Teachers were requested for their participation and due permission was taken from the school principal. They were all notified about the goals and intentions of the study. Participants were aware, from the beginning, of the details for participation. To protect anonymity, teachers, students and parents were assigned alphanumerical code numbers.

\subsection{FINDINGS}

Through analysis and coding of interviews, deep comments from the research scholars and the eminent educators, and the context of the working methods, fourteen categories emerged which characterized and described the online classroom from various perspectives and how the teachers practiced and strived for the incorporation of the 21st century skills. Analysis of the categories and on grouping brought into sight six themes as perceptions of online education and incorporation of 21 st century skills by teachers in their lessons emerged to answer the research questions.

The SIX themes are discussed below:
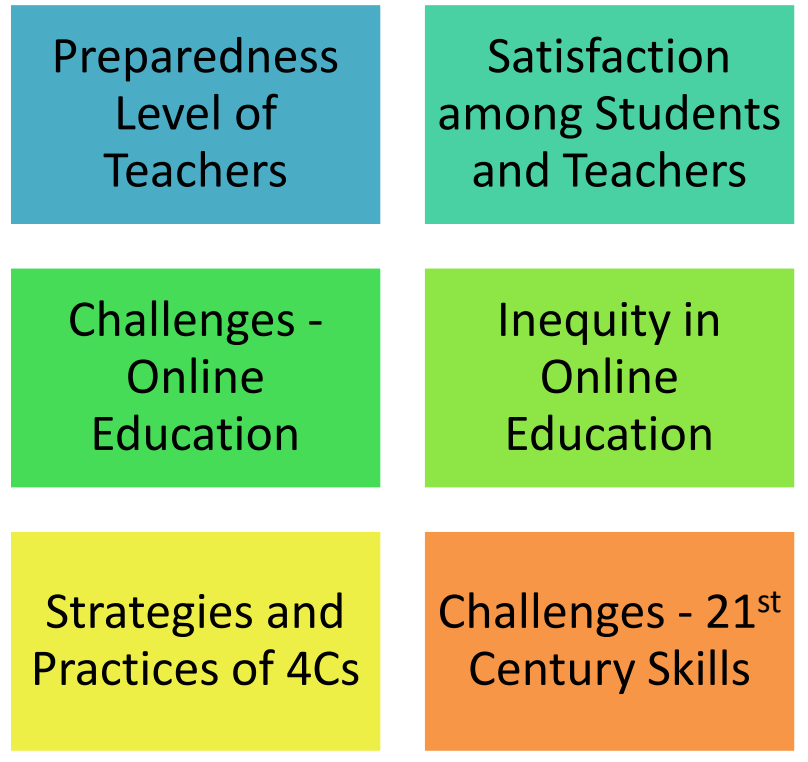

\subsection{Preparedness Level of Teachers}
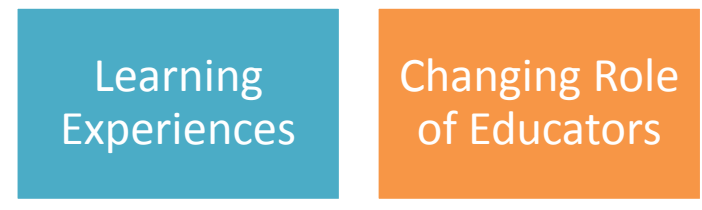

Covid-19 struck without a warning and left heads of all educational institutions scrambling to respond to its exigencies. It has also created a need to creatively deal with such unforeseen and once-in-acentury catastrophic events that are being predicted as the 'new normal'. School principals gave a swift response to the pandemic amid the lockdown restrictions. Their alacrity has resulted in a spate of online classes for learners of every level ranging from scholastic subjects, co-scholastic areas such as fine and performing arts to mental wellness and physical fitness. Nevertheless, for teachers switching over to the online mode of teaching is a huge challenge. They have managed to imbibe a number of hard and soft skills to be able to do it successfully to date. However, regular observation of their classes and constructive and timely feedback would definitely help them improve their skills. A good strategy would also be to ask them what they need to learn and to organize focused interventions to help meet their learning gaps.

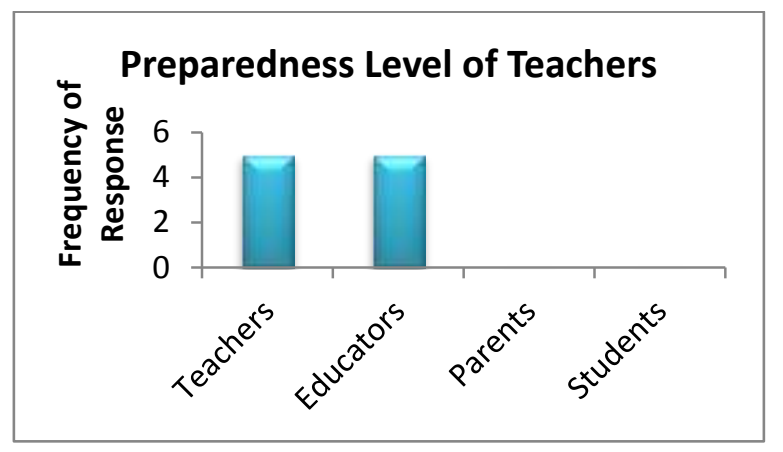

\subsubsection{Learning Experiences}

This emerged as a category for comments like: technophobia among teachers called fear of technology, some are willing but not exposed to new technology, some teachers cannot handle multiple platforms, they have resistance to change, they fear that students know more and can learn faster, insecurities prevail, lack of accessibility, lack of training, they need to be resourceful, familiarize with technology, learn internet and web search. Hence, the need of the hour is to move along a steeper learning curve.

For schools, training teachers to become adept at teaching online is a herculean task. Ensuring that they have the right hardware and good Internet connectivity is another. Helping teachers transition to virtual classrooms and essentially a brand-new way of doing things has virtually become a reality. Said a teacher, "The importance of classroom learning is undeniable and this pandemic proves that we are not yet ready to handle online classrooms,". Teachers spoke about needing more information regarding $21^{\text {st }}$ century skills and how to address them in lessons. Because of their uncertainty with $4 \mathrm{Cs}$ of $21^{\text {st }}$ century 


\section{EPRA International Journal of Research and Development (IJRD)}

skills, teachers in this study did not plan lessons with these skills in mind.

The suddenness with which teachers have been plunged into online teaching amid the lockdown means they did it with little preparation. Many schools also had no clear markers for how much they were trying to achieve through this changed process. For teachers, their online battles with learning and unruly students could leave impressions that last beyond the immediate concerns of the lockdown.

\subsubsection{Role of Educators}

A teacher has to play the role of a facilitator in the classroom, this means that the teacher should not be the king who controls the activities of the learners, but assist the learners in achieving goals, grant them some space for creativity and innovation, critical thinking, collaboration and communication. In other words, the learners must get involved into an active participation that would be represented in argumentative discussions and teamwork activities, so that the process of learning becomes comprehensive.

\subsection{Satisfaction among Students and Teachers}

The categories from which this theme was derived are:
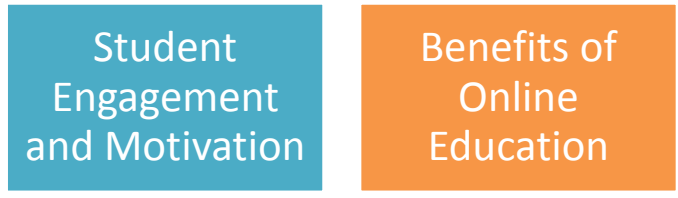

The study identified five elements of student satisfaction: learner relevance, active learning, authentic learning, learner autonomy, and technology competence. Overall there was a positive response from teachers, students, parents as well as the expert educators regarding online education. Thus the theme "Satisfaction among Students and Teachers" was received from the categories: benefits of online education and student engagement and motivation

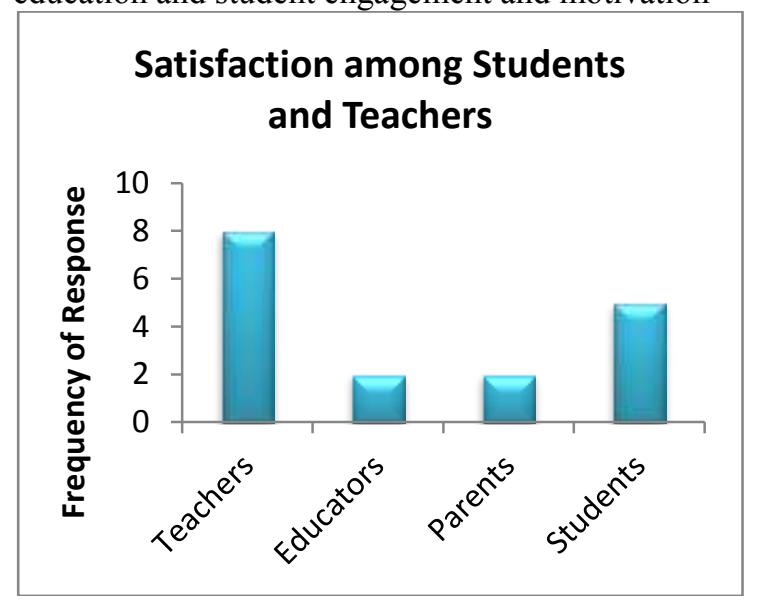

\subsubsection{Student engagement and motivation}

One teacher commented that "Online classes might last for four hours but we are required to put in almost the same amount of time preparing assignments which are not just useful but also attractive to keep the students engaged", she said. Students are motivated with active learning, using eBooks and attending Google class. Participative Learning is encouraged as it has interactive quiz eBooks, self reading material, various platforms are available, teachers use multimedia, social media like twitter etc. Video conferencing, synchronous and asynchronous learning is an additional to remain connected.

\subsubsection{Benefits of Online Education}

Online learning platforms help students become independent learners. Online education can also be designed to be accommodating of a variety of learning styles among students. As educators, additional efforts to incorporate online learning into the curriculum will need to be done. They are helping teachers/educators advance their skills in curriculum implementation, policy, education systems and leadership, both independently and with the support of their institutions. It lets them collaborate with their peers, and learn new instructional skills, that are relevant to their career. These help them develop new skills and capabilities in their students, with the help of technology and interdisciplinary approaches. Teachers get trainings, school support, attend international webinars, they prepare different types of lesson plans, lessons which are exciting and interesting to teach and are activity oriented. Of course trial and error, self learning is a part of the game. For students it means enjoyment and happiness with social media, children do not get tired at school through hot days, they are safe at home, they study, they play educational games. Teachers find that assessments are easier. Overall it is a good learning experience.

\subsection{Challenges - Online Education}

The categories from which this theme was derived are:
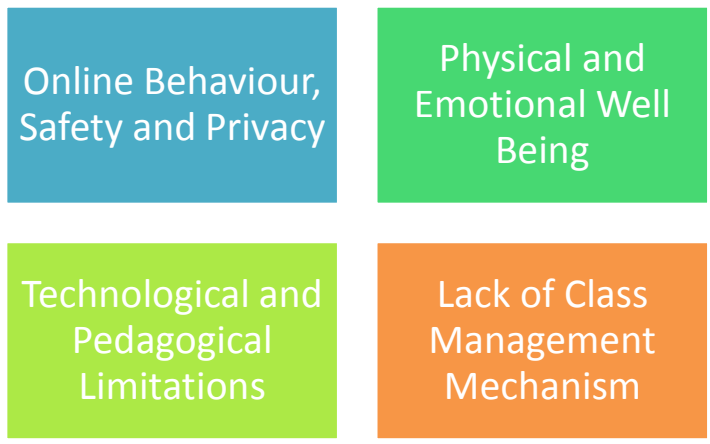

Lack of Class

Management

Mechanism 


\section{EPRA International Journal of Research and Development (IJRD)}

Comparing face-to-face learning with online learning brings forth significant deficiencies in the online mode such as lack of human connect, absence of opportunities of collaborative learning, teacher supervision and the most glaring being lack of opportunities for hands-on learning in complex teaching subjects such as science and mathematics. Besides, amid the rush of hosting online classes the best teaching practices such a addressing learners Multiples Intelligences (MI), VARK Learning Styles and providing a differentiated learning experience or even incorporating $21^{\text {st }}$ century skills have been relegated to the backburner. Various categories on this theme of online challenges came up.

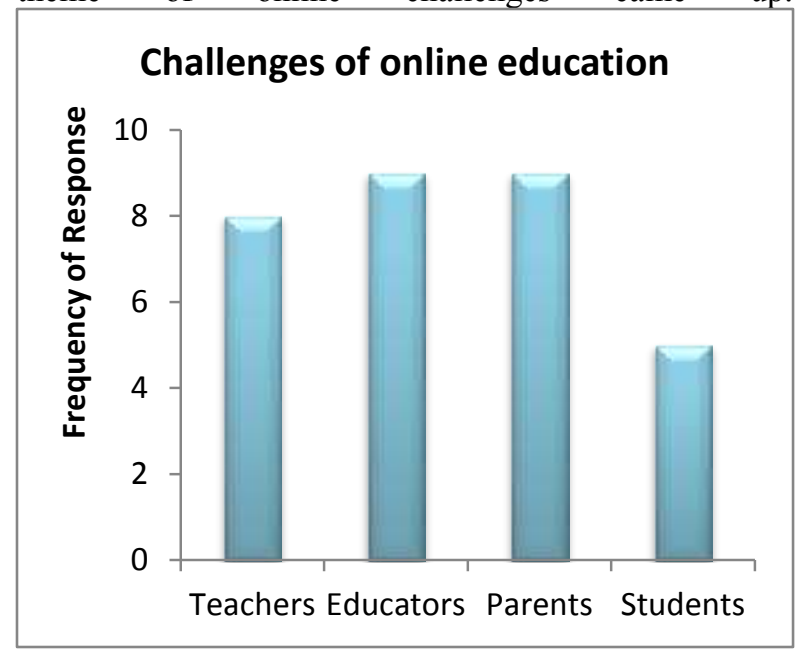

\subsubsection{Online Behaviour, Safety and Privacy}

In this time of corona virus, though, with lockdowns closing schools around the world, keeping children safe online has never been more critical. Although online learning has filled a lot of the gaps, what it means is that screen time has increased for many children. Around $60 \%$ of 8 - to 12 -year-olds are exposed to cyber risk, including cyber-bullying. It's important to teach children about cyber risks - cyberbullying, gaming addiction etc. COVID-19 is making the potential exposure to cyber risk greater, but it's not necessarily a causal effect. Causal effects of cyber risk are lack of knowledge, lack of discipline, uncontrolled and non-supervised digital use. Research shows limiting screen time and the kind of content being watched is related to better mental and physical health, and improved school grades and pro-social behaviour. But the fact is that digital surveillance is missing - that is the need of the hour and the parents and teachers as well as the experts are worried.

\subsubsection{Physical and Emotional Wellbeing:}

Schools and larger education systems have rallied to the charge and swiftly moved through two clear stages of change in the move to distance learning. The first focused on determining the technology platforms to use. The second stage has focused on adapting the delivery of academic curriculums for remote learning environments. These two stages are still in progress and teachers are on a steep learning curve. But as the dust begins to settle on Stage 1 (technology) and Stage 2 (academic curriculum), it has become apparent that a third stage is now needed in schools across the globe - how to teach social emotional learning in digital classrooms. Indeed, now more than ever, the mental health of our students is at risk with youth anxiety about the corona virus rising and our young people feeling isolated, disconnected and confused. Today's students have grown up as digital natives and are adept at learning online. They are always online. Parents worry about the lack of exercises and desire to play out in the park with friends. So there are effects of technology and online learning on student mental, emotional and social health.

\subsubsection{Lack of Class Management Mechanism}

More than anything, online classrooms have brought up the issues of classroom management. If teachers thought they had enough trouble keeping their classrooms in order earlier, that is nothing compared to the woes of remote classrooms. It is very sad to hear long-term educators asking for help with managing students online. How can I maintain discipline? How do I ensure students don't tamper with my presentation? How can I prevent students from disrupting the class? Can students disrupt my class? How? How can I keep the children attentive? What length of class is appropriate for them? They're so young, will online teaching even be effective for them? How can I ensure effectiveness?

\subsubsection{Technological and Pedagogical Limitations}

Teachers who are intimidated by technology now have to take the bull by its horns. For many who are proficient at planning and teaching in the traditional classroom, planning for an online setting requires some re-learning, Finding the right online teaching platform is just the first step. Learning how to use the various features correctly is important. But using a platform and its features to teach effectively and ensure that all students are indeed learning is paramount. 


\section{EPRA International Journal of Research and Development (IJRD)

\subsection{Inequity in Online Education}

The categories from which this theme was derived are:

\section{Digital Divide in Accessibility}

\section{Hardware and Structural Challenges}

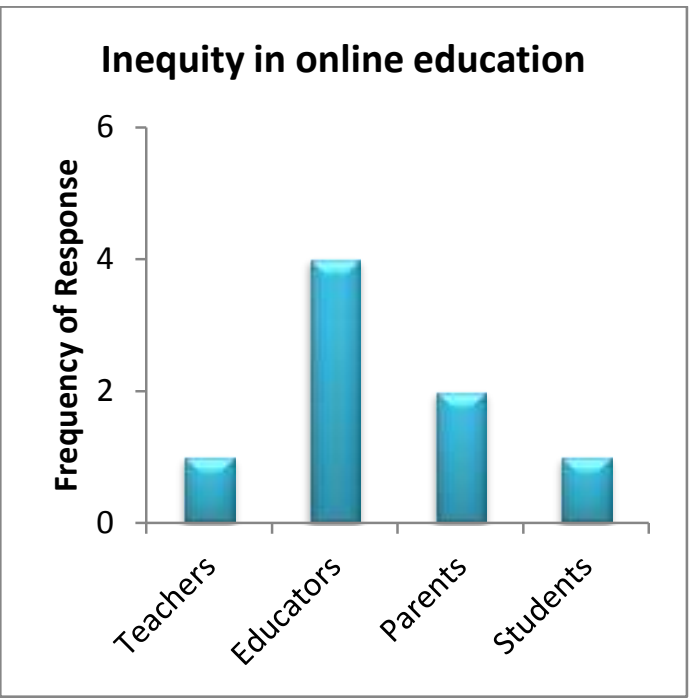

\subsubsection{Digital divide and Hardware and structural challenges}

This digital divide may be attributed to multiple factors - lack of infrastructure in terms of access to internet, absence or dearth of computers in schools, inability of underprivileged students to procure computers, and lack of digital literacy amongst both teachers and students. Mobile connectivity does not imply that every such person would also have access to the internet or that all such mobiles would be smart phones that can support e-learning technology. Even if it is assumed that most people having mobile phones have access, one cannot ignore the issue of lack of

digital literacy. Besides, now that entire families have been confined to their homes due to the lockdown, the only mobile or computer in the house is likely to be used by the parents who are working from home.

Rural India's poor internet penetration is further exacerbated due to low household incomes, frequent cable cuts, unreliable electricity and insufficient diesel supplies for generators in towers. While there are many unaddressed issues, the truth is that the experiment of a 'Digital India' remains a distant dream and a large population of students is gravely disadvantaged by this reality. Granted that the circumstances are peculiar, but it is the moral obligation of the State to ensure that fighting against COVID-19 does not exacerbate the disparities that already exist.

COVID-19 has brought to fore the fact that the right to internet is inextricably linked to the right to education.

\subsection{Strategies and Practices of $4 \mathrm{Cs}$}

The categories from which this theme was derived are: Practitioners
Strategies of

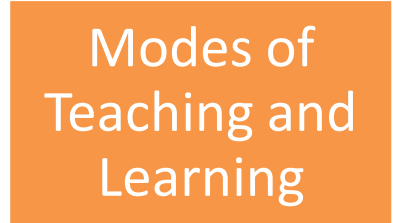

The $21^{\text {st }}$ Century Skills are the skills that are required by an individual for his/her holistic development so that he/she can contribute to the progress and development of his society/ nation and world. Empowering students with these skills is a challenging task (NCERT, 2020).

\section{Strategies and Practices of 4Cs}

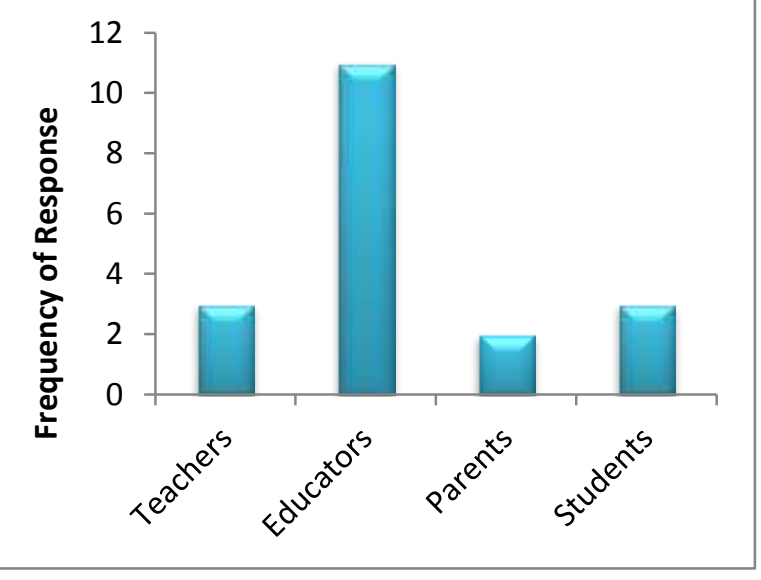




\section{EPRA International Journal of Research and Development (IJRD)}

3.5.1 Strategies of Practitioners For practitioner facilitating incorporation of $4 \mathrm{Cs}$ of $21^{\text {st }}$ century skills, online learning theory suggests that instructional practices must be modified in order to fit with technology. Teaching should not be approached in the same way when technology is utilized (Ally, 2008). To effectively incorporate $21^{\text {st }}$ century skills with technology and classroom content, different instructional methods can assist teachers with the integration of all areas, enabling teachers to teach content and $21^{\text {st }}$ century skills effectively and efficiently. Utilizing instructional methods such as problem-based learning (PBL). In PBL, groups of students collaborate to problem solve a complex problem-based on classroom content. Through these types of problem solving, students are exposed to all $21^{\text {st }}$ century skills, while also learning classroom content.

\subsubsection{Mode of teaching and learning: All} stakeholders were of the opinion that a mix or blend of online and offline (face to face interaction) is more acceptable than either of them completely. Hopefully, when classes resume, after the pandemic settles a bit, in the partial mode, a fair division could be evolved in online-offline practice to ensure that learning outcomes and achievements do not slip.

\subsection{Challenges in Incorporation of $2^{\text {st }}$ century skills}

The categories from which this theme was derived are:

\section{Lack of Awareness and Resources}

Deficiencies in Holistic Development
The next and final theme that emerged from the data was the challenges encountered in incorporation of $21^{\text {st }}$ century skills

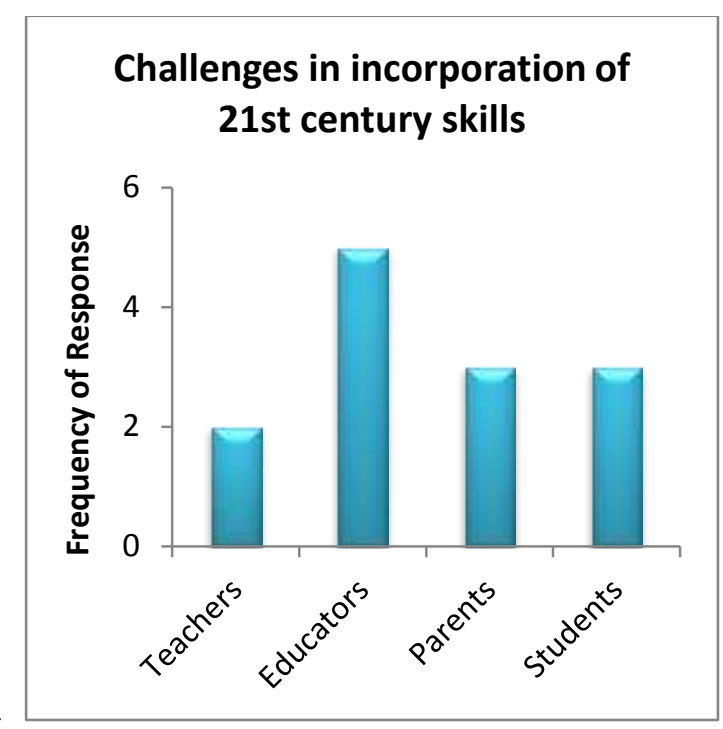

3.6.1 Lack of awareness and resources: Teachers in this study had limited knowledge of $21^{\text {st }}$ century skills and, therefore, were unsure about how to incorporate these skills into lessons with technology, with the exception of communication and collaboration, which, in some cases, was facilitated by technology. In fact in the interview one of the teachers mentioned that they embed $21^{\text {st }}$ century skills rather randomly in their lessons.

\subsubsection{Deficiencies in Holistic Development}

In holistic education children need to develop the ability to survive in the modern world, not just in academics. They need to meet challenges of the future andcontribute to the world in which they live. An expert teacher educator feels that, "Online learning experiences might lead to the mental and intellectual development of the learners, if the learners are serious enough to study. The other developmental areas like physical, psychological, social, emotional and moral are highly neglected. The outcome of such learning would not lead to the all round development of the learners."

\section{CONCLUSION}

Since March 2020, COVID-19 has disrupted normal life including the closure of educational institutions. It has upended academic sessions, led to the scrapping of examinations, delayed admissions for 


\section{EPRA International Journal of Research and Development (IJRD)}

the new academic sessions and seriously unsettled the plans of those who had geared up to join the workforce or planned to study abroad. COVID-19 has impacted over 240 million students and 9.5 million teachers. This indefinite closure of schools has created an alarming learning vacuum for students. In a bid to ensure continuity in learning, many states and schools began online learning and teachers resorted to emergency remote teaching. Although online education did provide critical service to bridge the gap, it did not turn out to be the silver bullet. A blend of offline-online learning should be the path for the future. This is because the transition from brick and mortar school to technology based learning has its challenges: Unequal access to devices, poor internet connectivity, inadequate space at home to do online schooling for multiple children simultaneously, teachers lacking training to deliver online classes, short supply of customized online content and the impact of continuous exposure to screen time on health. These realities must be acknowledged.

In a country as diverse as India, the delivery of tech-driven education cannot follow a one-size-fits-all approach. It is important to know that education is not only about technology integration but also about learning, learning outcomes, interaction, holistic development, and life skills for 21 st century, building up of social and human capital, which only brick and mortar can provide - a real people platform where minds meet. This idea of holistic education has been neatly incorporated in the National Education Policy, 2020 released recently by the Ministry of Education, NewDelhi.

\section{BIBLIOGRAPHY}

1. Azmi, M. N. \& Nurzatulshima (2017). International Research Journal of Education and Sciences (IRJES), Vol.1 Special Issue 1 (Malay). eISSN25502158.

2. Baiyere, A. \& Li, H. (2016). 'Application of a virtual collaborative environment in a teaching case'. In AMCIS 2016: Surfing the IT Innovation Wave - 22nd Americas Conference on Information Systems.

3. Baig, M.A. (2011). A critical study of effectiveness of online learning on students' achievement. Retrieved on 2 July 2020 from https://files.eric.ed.gov/fulltext/EJ1102153.pdf

4. Bakia, M., Shear, L., Toyama, Y. \& Lasseter, A. (2012). Understanding the implications of online learning for educational productivity. Jessup, MD: U.S.

5. Department of Education, Office of Educational Technology.
6. Bedir, H. (2019). Pre-service ELT teachers' beliefs and perceptions on the $21^{\text {st }}$ century learning and innovation skills (4Cs). Journal of Language and Linguistic Studies, 15(1), 231-246. Doi:10.17263/jlls.547718

7. Bellanca, J., \& Brandt, R. (2014). 21st century skills: Rethinking how students learn.

8. Bloomington, IN: Solution Tree. Creative Education, Vol.5 No.9, May 26, 2014 Beers, S.Z. (2012). 21st century skills: Preparing students for their future. www.mheonline.com/mhmymath/pdf/21st century_skills.pdf

9. Best, J.W. \& Kahn, J.V. (2008). Research in Education. (10thed.). New Delhi: Prentice Hall of India.

10. Bloor, M., and Wood, F. (2006). Keywords in qualitative methods. Thousand Oaks, CA: Sage.

11. Creswell, J. W. \& Plano Clark, V. L. (2007). Designing and conducting mixed methods research. Thousand Oaks, CA: Sage.

12. Czarnecki, K. (2009). Technology leadership. Teacher Librarian, 37(2), 75 -76. DarlingHammond, L. (2006). Constructing 21st century teacher education. Journal of Teacher Education, 57, 300-314. doi:10.1177/0022487105285962.

13. Dede, C. (2007). Reinventing the role of information and communications technologies in education. Yearbook of the National Society for the Study of Education, 106(2), 11-38.

14. Dikshit, J., Garg, S. \& Panda, S. (2013). Pedagogic Effectiveness of QR Print, Interactive Multimedia, and Online Resources: A Case Study. International Journal of Instruction, Vol.6, No.2 e-ISSN: 13081470

15. Ellinger, A.D., Watkins, K.E. \& Marsick, V.J. (2005). Case study research. R.A. Swanson\& E.F. Holton III (Eds.), Research in Organizations (pp. 327 -350). San Francisco: Berrett-Koehler Publishers.

16. Erdoğan, V. (2019). Integrating $4 C$ Skills of 21 st Century into 4 Language Skills in EFL Classes International Journal of Education and Research Vol. 7 No. 11 November 2019ISSN: 2411-5681 Retrieved from www.ijern.com Germann, T. C., et al. (2019). 'School dismissal as a pandemic influenza response: When, where and for how long?', Epidemics, 28(June), 100348. https://doi.org/10.1016/j.epidem.2019.100348

17. Gibbs, G.R. (2007). Thematic Coding and Categorizing, Analyzing Qualitative Data. SAGE Publications Ltd., London.

18. Greg, Lindon. (2011). Computers in Education should Target Test Scores, Oct, 10, 2011 Educational Blogs, Communications of the ACM Journal, New York.

19. Ghose, I. (2011). Connecting Teacher Globally, Microsoft India releases Interviews, digital Learning, New Delhi, Dec-2011. 


\section{EPRA International Journal of Research and Development (IJRD)

20. Jackson, T. (2012). Transforming learning in cities. A global cities education network Report. Asia Society: Partnership for Global Learning report. Kay, K. \& Greenhill, V. (2010). Twenty-First Century Students Need 21st Century Skills. 10.1007/978-94-007-0268-4_3.

21. Kereluik, K., Mishra. P., Fahnoe, C. \& Terry, L. (2013). What Knowledge is of Most Worth: Teacher Knowledge for 21st Century Learning. Journal of Digital Learning in Teacher Education, Volume 24, No. 4

22. Lauran, A. G. (2008). Fostering collaboration to enhance online instruction. Turkish Online Journal of Distance Education, 9(2), 109-121.

23. Maxwell, J.A. (2005). Qualitative research design: An interactive approach. Thousand Oaks, California: Sage Publications, Inc.

24. Merriam, S. B. (2009). Qualitative research: A guide to design and implementation. San Francisco, California: Jossey Bass.

25. Miller, P. (2011). Theories of developmental psychology. New York, NY: Worth Publishers.

26. Mishra, P. \& Kereluik, K. (2011). What 21st Century Learning? A Review and a synthesis. Paper submitted to the 2011, SITE Conference. Michigan State University. National Curriculum Framework - 2005. New Delhi: NCERT

27. National Policy on Education - Programme of Action. (1992). New Delhi: MHRD, Government of India. Organization for Economic Cooperation and Development (2005). The definition and selection of key competencies: Executive Summary. Paris, France: OECD Partnership for 21st Century Learning (2012). Framework for 21st Century Learning. $\quad$ Retrieved from https://www.battelleforkids.org/networks/p21

28. Pellegrino, J.W. \& Hilton, M.L. (2013). Education for Life and Work: Developing Transferable Knowledge and Skills in the 21st Century. National Academy of Sciences. National Academies Press. Raj, M. (2012). Effectiveness of electronic classroom for teaching General science at secondary school level. MIER Journal of educational studies, 2012.

29. Ravitch, S. \& Riggan, M. (2012). Reason \& rigor: How conceptual frameworks guide research. Thousand Oaks, California: Sage Publications.

30. Ryan, A.M. (2000). Peer groups as a context for the socialization of adolescents' motivation, engagement, and achievement in school. Educational Psychology, 35(2), 101-11.

\section{WEB REFERENCES}

1. https://theprint.in/india/education/why-onlineclasses-may-not-be-such-agood-idea-after-allespecially-for-kids/406979/

2. http://www.cbse.nic.in/cce/life_skills_cce.pdf

3. https://www.battelleforkids.org/networks/p21
4. https://indianexpress.com/article/technology/technews-technology/onlineclasses-why-teachinglearning-remotely-learning-experience-6367765/

5. http://etec.ctlt.ubc.ca/510wiki/Theory_of_Online_L earning

6. https://auspace.athabascau.ca/bitstream/handle/21 49/757/toward_a_theory_of.pdf? sequence $=3$

7. https://er.educause.edu/articles/2020/3/thedifference-between-emergencyremote-teachingand-online-learning

8. http://research.acer.edu.au/cgi/viewcontent.cgi?arti cle $=1002 \&$ context $=$ lsay_conference

9. https://www.theweek.in/news/india/2020/05/23/onli ne-classes-turning-out-tobe-nightmare-forteachers-amid-covid-19-lockdown.html

10. https://www.teachingenglish.org.uk/blogs/tamerosman/how-can-teacher-be-afacilitator 